\title{
Production of Cuticle-degrading Enzymes by the Entomopathogen Metarhizium anisopliae during Infection of Cuticles from Calliphora vomitoria and Manduca sexta
}

\author{
By RAYMOND J. ST LEGER, * RICHARD M. COOPER AND \\ A. KEITH CHAR NLEY \\ Department of Crop Protection, School of Biological Sciences, University of Bath, \\ Claverton Down, Bath, Avon BA2 7 AY, UK
}

(Received 2 September 1986; revised 20 November 1986)

\begin{abstract}
A biochemical and histochemical investigation with specific substrates and inhibitors was used to visualize protease, esterase and aminopeptidase activities produced in situ during penetration of Calliphora vomitoria and Manduca sexta cuticles by hyphae of the entomopathogenic fungus Metarhizium anisopliae. Two endoproteases, and aminopeptidase and esterase activities, were mainly localized in simple and complex appressoria and germinating conidia. The effect of inhibitors on two characterized proteases ( $\operatorname{Prl}$ and $\operatorname{Pr} 2)$ and aminopeptidase activity in appressorial plates was quantified by microdensitometric measurement of reaction products. $\operatorname{Pr} 1$ and $\operatorname{Pr} 2$ activities were differentially inhibited by various protease inhibitors. $\operatorname{Pr} 1, \operatorname{Pr} 2$, esterase, aminopeptidase and $\mathrm{N}$-acetylglucosaminidase (exochitinase) activities were present during penetration as detected directly following desorption from fungal and cuticle components. The proteases produced in situ were fractionated, and were shown by immunological and enzymological criteria to be the same as those produced in culture media. The sequence of enzyme appearance in situ showed that production of proteolytic enzymes precedes exochitinase production. No production of endochitinase was found before or during hyphal penetration of the cuticle.
\end{abstract}

\section{INTRODUCTION}

Insect pathogenic (entomopathogenic) fungi invade their hosts primarily through the exoskeleton or cuticle. This mode of entry is similar to that of plant pathogenic fungi and is believed to be achieved by a combination of mechanical pressure and enzymic degradation (Charnley, 1984). Entomopathogenic fungi produce in culture enzymes capable of digesting the major components of unsclerotized insect cuticle (St Leger et al., 1986a, b). It is necessary, however, to establish that these enzymes are produced in vivo before their role in pathogenesis can be elucidated. Previous studies of putative cuticle-degrading enzymes have been based on histochemical detection. Ratault \& Vey (1977) demonstrated that hyphae of Metarhizium anisopliae produced a non-specific esterase and $N$-acetylglucosaminidase in the cuticle of Orycetes rhinoceros. Gabriel (1968) similarly obtained a positive histochemical result for lipase at

\footnotetext{
Abbreviations: amino acid abbreviations are those proposed by the IUPAC-IUB Commission on Biochemical Nomenclature (see European Journal of Biochemistry 27, 201-207, 1972); all amino acids used were Lconfiguration. Other abbreviations were as follows: $\mathrm{CBZ}, \mathrm{N}$-benzyloxycarbonyl; BOC, tert-butyloxycarbonyl; Ben, benzoyl, Suc, succinyl; MNA, 4-methoxy-2-naphthylamine; 2NA, 2-naphthylamine; NA, p-nitroaniline; $p N P, p$-nitrophenol; $\mathrm{CH}_{2} \mathrm{Cl}$, chloromethyl ketone; DMA, $N, N$-dimethylacetamide; DMF, $N, N$. dimethylformamide; FBB, fast blue B (tetrazotized diorthoanisidine); FITC-WGA, fluorescein isothiocyanate conjugated wheat germ agglutinin; IEF, isoelectric focusing; MBTH, 3-methyl-2-benzothiazolinone hydrazone; MIA value, mean integrated absorbance value; PMSF, phenylmethylsulphonyl fluoride; TEI, turkey egg white inhibitor.
} 
the point of entry by Entomophthora sp. In the most comprehensive study to date Michel (cited in Fargues, 1984) demonstrated that conidia and appressoria of Beauveria bassiana produced lipase/esterase and $\mathrm{N}$-acetylglucosaminidase, but no apparent protease activity, on the cuticle surface of Galleria mellonella. This failure to find protease activity is important since all entomopathogens produce extracellular proteases; they are synthesized rapidly and in large amounts compared with chitin-degrading enzymes in culture media containing cuticle (St Leger et al., 1986a); also protein, not chitin, is the predominant matrix polymer of the cuticle (St Leger et al., 1986b). This suggests that the proteases may have a major role in cuticle degradation in vivo.

In the present study qualitative and quantitative histoenzymological techniques were combined with procedures for extraction of enzymes from fungal-colonized cuticle. Biochemical and immunological techniques were then used to compare the temporal and spatial production of putative cuticle-degrading enzymes in situ and in culture.

\section{METHODS}

Organism and growth. The fungal isolate (Metarhizium anisopliae ME1), culture media and preparation of locust cuticle were described by St Leger et al. (1986a).

Chemicals. Except for hide protein azure (Calbiochem), CBZ-(Gly) ${ }_{2}$-Arg-MNA (Koch-light) and Suc-(Ala) ${ }_{2}$ Pro-Phe-MNA (Enzyme systems, California, USA), all enzyme substrates were from Sigma.

BOC-Gly-Leu-Phe- $\mathrm{CH}_{2} \mathrm{Cl}$ was generously provided by Professor J. C. Power, Georgia Institute of Technology, Atlanta, USA. The other enzyme inhibitors and FITC-WGA were from Sigma. Calcofluor M2R New was from Cyanamid. Pure grade FBB was from Serva. Ampholines were from Pharmacia. Other chemicals used were commercial products of analytical grade.

Insect culture. Rearing conditions for the desert locust Schistocerca gregaria were described by St Leger et al. (1986a). Wandering larvae of the blowfly Calliphora vomitoria were purchased from Bio-Serv and allowed to pupate in sawdust at room temperature $\left(22^{\circ} \mathrm{C}\right)$. Emergence of flies was synchronized by refrigerating $\left(4^{\circ} \mathrm{C}, 24 \mathrm{~h}\right)$ pharate adults which were about to emerge. The adults were maintained at $22^{\circ} \mathrm{C}$ and fed solely on sucrose. Larvae of the tobacco hornworm Manduca sexta were reared according to Bell \& Joachim (1976).

Extraction of enzymes from blowfly wings. Insects were killed by freezing and surface-sterilized in an atmosphere of ethylene oxide. Wings were dissected away, washed in sterile distilled water and placed on the surface of water agar $(1.5 \%$, w/v) plates. For most experiments $15 \mu \mathrm{l}$ distilled water containing about $1500 \mathrm{M}$. anisopliae conidia was pipetted onto the exposed upper surface of each wing. The drop was allowed to dry before infected and uninfected (control) wings were incubated (up to $40 \mathrm{~h}$ at $27.5^{\circ} \mathrm{C}$ and $100 \%$ relative humidity; after $40 \mathrm{~h}$ infected wings became fragile preventing further experimentation), checked microscopically to ensure there was no bacterial contamination, and then extracted by vigorously shaking for $1 \mathrm{~h}$ in $0.2 \mathrm{M}$-potassium phosphate buffer, $\mathrm{pH} 7.0$ (two wings $\left.\mathrm{ml}^{-1}\right)$ at $4^{\circ} \mathrm{C}$. After centrifugation $\left(5000 \mathrm{~g}, 10 \mathrm{~min}, 4^{\circ} \mathrm{C}\right)$ extracts were dialysed $(200 \mathrm{vols}$ distilled water, pH 6.0) before assaying for enzyme activities. In some experiments wings were finely comminuted under liquid nitrogen using a pestle and mortar. The ground tissue was used simultaneously as enzyme source and substrate by shaking in buffer $\left(1 \mathrm{mg} \mathrm{ml}^{-1}\right)$ at $\mathrm{pH} \mathrm{6.0} \mathrm{(0.05} \mathrm{M-citric} \mathrm{acid/sodium} \mathrm{phosphate} \mathrm{buffer)} \mathrm{or} \mathrm{pH} 8.0$ $\left(0.02 \mathrm{M}-\mathrm{HEPES} / \mathrm{NaOH}\right.$ buffer) at $30^{\circ} \mathrm{C}$ under toluene. Control wings were uninfected, or infected and heated $\left(80^{\circ} \mathrm{C}, 20 \mathrm{~min}\right)$. At $0 \mathrm{~h}$ and $24 \mathrm{~h}$ reaction mixtures were filtered through Millex-HV $0.45 \mu \mathrm{m}$ filter units and filtrates tested for free amino groups (ninhydrin: Moore \& Stein, 1948) and amino sugars [3-methyl-2benzothiazolinone hydrazone (MBTH): Smith \& Gilkerson (1979)]. Unlike other procedures for amino sugar determination those utilizing MBTH are reported to be highly specific and sensitive. However, having tested each of the amino acid constituents of insect cuticle we noted interference by the minor components threonine and phenylalanine (which gave about $5 \%$ of the colorimetric yield produced by $N$-acetylglucosamine). In contrast to the amino acids, detection of $\mathrm{N}$-acetylglucosamine required its hydrolysis to glucosamine (at $110^{\circ} \mathrm{C}$ for $2 \mathrm{~h}$ ); thus to compensate for possible interference by the two amino acids additional controls were included in which this hydrolysis step was eliminated.

Extraction of enzymes from Manduca sexta cuticle. Cuticles from fifth instar ( $3 \mathrm{~d}$ after ecdysis) Manduca sexta were removed from other tissues by dissection under $70 \%$ ethanol (Hackman, 1980), soaked in $0.001 \%$ phenylthiourea $(1 \mathrm{~h})$, surface-sterilized in $5 \%$ sodium hypochlorite $(5 \mathrm{~min})$ and rinsed with four changes $(5 \mathrm{~min}$ each) of sterile distilled water. Cuticles (about $3 \times 2 \mathrm{~cm}$ ) were placed on water agar $(1.5 \%$, w/v) plates, the cuticle surfaces dried in a sterile-air-flow cabinet and inoculated with $50 \mu \mathrm{l}$ distilled water containing about 5000 conidia. Following incubation $(60 \mathrm{~h})$ at $27.5^{\circ} \mathrm{C}$, cuticles were checked microscopically to ensure there was no bacterial contamination and enzymes were extracted as described for fly wings.

Enzyme assays. Non-specific protease activity (vs hide protein azure), elastase activity (vs elastin congo red) and activity vs Suc-(Ala) $)_{2}$-Pro-Phe-NA or Ben-Phe-Val-Arg-NA were assayed as described by St Leger et al. (1987). 
Protease activity vs MNA substrates in vitro was assayed in reaction mixtures containing $0.2 \mathrm{ml}$ substrate $(1.5 \mathrm{mM}$ Suc-(Ala) ${ }_{2}$-Pro-Phe-MNA or CBZ-(Gly $)_{2}$-Arg-MNA), $1.8 \mathrm{ml} \mathrm{Tris/HCl} \mathrm{buffer} \mathrm{(20} \mathrm{mM,} \mathrm{pH} \mathrm{8.2)} \mathrm{and} 0.5 \mathrm{ml} \mathrm{enzyme.}$ After $5 \mathrm{~min}$ at $25^{\circ} \mathrm{C}$ the reaction was terminated by addition of $0.1 \mathrm{ml} \mathrm{HCl}(1 \mathrm{M})$ followed by $1 \mathrm{ml} F B B$ ( $\left.1 \mathrm{mg} \mathrm{m}^{-1}\right)$; $10 \mathrm{~min}$ were allowed for full development of the red colour $\left(\lambda_{\max .} 525 \mathrm{~nm}\right)$. Aminopeptidase activity (vs Ala-2NA), esterase activity (vs $p$ NP-propionate), lipase activity (vs olive oil), $N$-acetyl- $\beta$-D-glucosaminidase activity (vs $p$ NP- $\beta$ - $N$-acetylglucosamine) and chitinase activity (vs colloidal chitin) were assayed as described by St Leger et al. $(1986 a)$.

Enzyme purification and characterization. Extracts (in $0.2 \mathrm{M}$-potassium phosphate buffer, pH 7.0) from 200 infected blowfly wings ( $30 \mathrm{~h}$ post-inoculation) were dialysed ( $14 \mathrm{~h}$ with 200 vols distilled water, $\mathrm{pH} \mathrm{6.0)}$ and concentrated with polyethylene glycol $\left(M_{\mathrm{r}} 20000\right)$ before fractionating by IEF [LKB $8101110 \mathrm{ml}$ column, pH range 3.5-10.0, as described by St Leger et al. (1986b)]. Chymo-elastase (Pr1) and trypsin-like enzyme (Pr2) produced in vivo and purified from $1 \%$ casein/basal salts media (St Leger et al., 1987) were compared by means of specific peptide substrates and specific inhibitors, as described by St Leger et al. (1987).

Chitinase was obtained from cultures of $M$. anisopliae on $1 \%$ chitin/basal salts media (St Leger et al., 1986b).

Histochemical localization of cuticle-degrading enzymes. Protease substrates were dissolved in DMF [except for Suc-(Ala $\left.{ }_{2}\right)$-Pro-Phe-MNA which was soluble in buffer] and diluted to $1.5 \mathrm{mM}$ concentrations $(1 \%, \mathrm{v} / \mathrm{v}, \mathrm{DMF})$ with 2 mM-potassium phosphate buffer ( $\mathrm{pH} 7 \cdot 5)$ containing FBB $\left(1 \mathrm{mg} \mathrm{ml}^{-1}\right)$. Infected blowfly wings were incubated for up to $2 \mathrm{~h}$ at $25^{\circ} \mathrm{C}$.

Aminopeptidase substrates $(1.5 \mathrm{~mm})$ dissolved in $2 \mathrm{~mm}$-potassium phosphate buffer $(\mathrm{pH} 7.0)$ containing FBB $\left(1 \mathrm{mg} \mathrm{ml}^{-1}\right)$ were incubated with infected wings at $25^{\circ} \mathrm{C}$ for up to $2 \mathrm{~h}$. A positive result for protease and aminopeptidase was indicated by an amorphous red precipitate.

Esterase substrates dissolved in acetone were diluted to $1.2 \mathrm{mM}(1.25 \%$ acetone) with $20 \mathrm{~mm}$-potassium phosphate buffer ( $\mathrm{pH} \mathrm{7.4)} \mathrm{containing} \mathrm{FBB}\left(3.75 \mathrm{mg} \mathrm{ml}^{-1}\right.$ ). Infected blowfly wings were incubated for up to $15 \mathrm{~min}$ at $25^{\circ} \mathrm{C}$. A violet precipitate indicated a positive result.

The lipase/esterase substrate naphthol-AS-nonanoate, dissolved in DMÁ, was diluted to $0.5 \mathrm{mM}$ concentration ( $1 \%, \mathrm{v} / \mathrm{v}, \mathrm{DMA})$ with $10 \mathrm{mM}-\mathrm{Tris} / \mathrm{HCl}$ buffer $\left(\mathrm{pH} \mathrm{7.4)}\right.$ containing FBB $\left(1 \mathrm{mg} \mathrm{ml}^{-1}\right)$; infected wings were incubated for $1-4 \mathrm{~h}$ at $25^{\circ} \mathrm{C}$. A violet precipitate indicated a positive result.

Lipase substrates $(0.2 \%$ Tween 40,60 or 80 ) dissolved in $50 \mathrm{mM}$-Tris/ $\mathrm{HCl}$ buffer $(\mathrm{pH} 7 \cdot 3)$ containing $0.4 \%$ $\mathrm{CaCl}_{2}$ were incubated with infected wings at $15^{\circ} \mathrm{C}$ for $3-7 \mathrm{~h}$. Fatty acids released by the action of lipases were precipitated as calcium salts; these were converted to lead salts and demonstrated as lead sulphide (Gomori, 1945). To prevent non-specific lead deposition the lead solution was reduced in concentration from $1 \%(G o m o r i, 1945)$ to $0.2 \%$.

After each histoenzymological staining procedure wings were rinsed in water, mounted on slides, and observed immediately. Controls for each test were produced by heating infected cuticle for $20 \mathrm{~min}$ at $80^{\circ} \mathrm{C}$ to inactivate enzymes. Additional controls were provided by omitting an essential factor from the incubation medium e.g. substrate, $\mathrm{FBB}$ or $\mathrm{CaCl}_{2}$ (from the Tween-containing media).

Quantitative histochemistry of protease and aminopeptidase activities. The rate of production of red azo-dye complexes was quantified with a Vickers M86 scanning-integrating microdensitometer. The measurements were made at $525 \mathrm{~nm}$ with a $\times 40$ objective and measuring spot diameter of $1 \mu \mathrm{m}$. Infected wings were immersed in the reaction mixture $(5 \mathrm{~s})$ and placed between a slide and coverslip. The wing hairs helped to ensure an even distribution of the reaction mixture. Focusing and selecting a suitable infection structure (appressorial plate) took about $1 \mathrm{~min}$ after which readings were taken every $20 \mathrm{~s}$. The temperature of the slide remained at $24-26^{\circ} \mathrm{C}$.

The rate of reaction (in MIA values $\mathrm{min}^{-1}$ ) obtained for single appressorial plates from five wings was calculated for each treatment. The values given are corrected for spontaneous azo-dye formation in heat-treated $\left(80^{\circ} \mathrm{C}, 20 \mathrm{~min}\right)$ appressorial plates.

Fluorescence staining of fungal material. This was done with FITC-WGA or Calcofluor M2R New as described by St Leger et al. (1986a).

Scanning electron microscopy. Infected cuticles were fixed for $12 \mathrm{~h}$ with $3-4 \%$ glutaraldehyde in sodium cacodylate buffer $(0.1 \mathrm{M}, \mathrm{pH} 7 \cdot 2)$, then washed and further fixed for $1 \mathrm{~h}$ in $1 \%(\mathrm{w} / \mathrm{v})$ osmium tetroxide in the same buffer. The samples were dehydrated in a graded series of acetone, then critical-point dried in a Polaron E3000, and coated with gold in a Polaron sputter-coater. Upper surfaces of the cuticle were viewed and photographed through a JEOL J5C scanning microscope at $15 \mathrm{kV}$.

Alternatively, infected cuticles were frozen in liquid nitrogen and freeze-dried in an Edward Pearse tissue dryer EPD3 before gold-sputtering. This method caused some deformation and shrinkage of fungal structure but unlike critical-point drying preserved the appressorial mucoid sheath.

Raising of antisera. A specific antiserum vs $\operatorname{Prl}$ was raised from an antigen-immunoadsorbent complex (Stevenson, 1974; Starkey \& Barrett, 1976). Prl (0.94 mg) purified to electrophoretic homogeneity (St Leger et al., 1987) was dissolved in $0.05 \mathrm{M}$-potassium phosphate buffer, $\mathrm{pH} 7.0$, containing $0.5 \mathrm{M}-\mathrm{KCl}$ and adsorbed with $0.5 \mathrm{~g}$ chicken ovoinhibitor-sepharose complex prepared using $\mathrm{CN}-\mathrm{Br}$ Sepharose as described in the Pharmacia handbook 'Affinity Chromatography', The Prl-immunoadsorbent complex was then washed with 0.05 M- 
potassium phosphate buffer pH 7.0-0.5 $\mathrm{M}-\mathrm{KCl}(2 \times 30 \mathrm{ml}, 15 \mathrm{~min})$, suspended in phosphate-buffered saline $\left(0.8 \% \mathrm{NaCl}, 0.02 \% \mathrm{KCl}, 0.02 \% \mathrm{KH}_{2} \mathrm{PO}_{4}, 0.12 \% \mathrm{Na}_{2} \mathrm{HPO}_{4}\right)$ and stored at $-20{ }^{\circ} \mathrm{C}$ in three $1 \mathrm{ml}$ samples. One sample was mixed with an equal volume of Freund's complete adjuvant and injected intramuscularly into the thighs of a male Californian rabbit. The procedure was repeated after 2 weeks. For the final injection (after 4 weeks) Freund's incomplete adjuvant was used. Blood was taken 2 weeks after the final injection and incubated at $37^{\circ} \mathrm{C}$ for $1 \mathrm{~h}$ and then $4{ }^{\circ} \mathrm{C}$ for $18 \mathrm{~h}$ before serum separation by centrifugation at $2500 \mathrm{~g}\left(4^{\circ} \mathrm{C}\right)$.

Ouchterlony double immunodiffusion was performed for $24 \mathrm{~h}$ at $25^{\circ} \mathrm{C}$ in $1.2 \%$ agarose containing $0.1 \mathrm{M}$ potassium phosphate buffer ( $\mathrm{pH} 7 \cdot 0$ ), $0.15 \mathrm{M}-\mathrm{NaCl}, 0.05 \% \mathrm{NaN}_{3}$ and $2 \mathrm{mM}-\mathrm{PMSF}$.

\section{RESULTS}

\section{Behaviour of $M$. anisopliae conidia germinating on blowfly wings}

Conidial germination began at $6 \mathrm{~h}$ and reached about $68 \%$ between 8 and $24 \mathrm{~h}$; failure to germinate by $30 \mathrm{~h}$ was usually associated with clumping. Appressoria developed between 10 and $24 \mathrm{~h}$ as terminal swellings, up to $7 \mu \mathrm{m}$ diameter, on germ tubes (Fig. 1). Sub-terminal appressoria (lateral to germ tubes) developed from $16 \mathrm{~h}$. Appressorial production was not related to any discernable surface feature. Frequently, the original appressorial cell proliferated or long germ tubes encountered each other, so that an appressorial complex was formed.

Appressoria attached firmly to the cuticle by means of mucus (Fig. 2) and produced infection pegs from near their terminal edge which usually, but not invariably, succeeded in breaching the cuticle (Fig. 1).

\section{Detection of enzymes produced on insect cuticle}

No enzyme could be detected in extracts from uninfected blowfly wings during the course of the experiment or from infected wings within $8 \mathrm{~h}$ of inoculation (Fig. 3) (when germination was only about $3 \%$ ). Among the first enzymes detected on infected blowfly cuticle were those of the proteolytic complex, i.e. protease and aminopeptidase; activities were evident about $16 \mathrm{~h}$ after inoculation, coincident with the formation of large numbers of appressoria on the wing surface. Fractionation by IEF (Fig. 4) separated the endoprotease activity into chymo-elastase [pI about 10.0, degrades Suc-(Ala) $)_{2}$-Pro-Phe-NA and elastin-congo red, inhibited by BOC-Gly-Leu-Phe$\mathrm{CH}_{2} \mathrm{Cl}$ and TEI] and trypsin (pI 4.5, degrades Ben-Phe-Val-Arg-NA, inhibited by Tos-Lys$\mathrm{CH}_{2} \mathrm{Cl}$ ) components, closely resembling the two alkaline serine enzymes ['chymo-elastase' ( $\mathrm{Pr} 1$ ) and 'trypsin-like' (Pr2); St Leger et al.(1987)] produced in culture on casein or on ground locust cuticle.

A third protease $(\operatorname{Pr} 3)$, present in culture filtrates and with an acidic $\mathrm{pH}$ optimum, was not detected in vivo ( $₹ 40 \mathrm{~h}$, post-inoculation). The material desorbed with $0.2 \mathrm{M}$-potassium phosphate buffer $\mathrm{pH} 7.0$ from infected blowfly cuticle was also tested by Ouchterlony gel diffusion (not shown) against specific antiserum to Prl and gave a single precipitin line identical to that given by the pure enzyme confirming the presence of Prl during infection. Similar results were obtained when the chymo-elastase produced in vivo, and isolated by IEF fractionation, was substituted for the crude extract. Selective removal of Prl from crude extract or culture filtrate (containing $0.2 \mathrm{M}-\mathrm{KCl}$ ) by passage through a TEI-sepharose column eliminated the precipitin reaction.

Overnight dialysis of wing extract against $\mathrm{Na}_{2}$ EDTA $(5 \mathrm{~mm})$ severely inhibited the aminopeptidase $(>80 \%)$, thus distinguishing this activity from that of the proteases which was unaffected. $N$-Acetylglucosaminidase and esterase activities were also obtained from wings $16 \mathrm{~h}$ after inoculation. Esterase production closely followed that of the protease and was also inhibited by PMSF ( $2 \mathrm{mM}$ ). $N$-Acetylglucosaminidase, however, was produced only at a slow rate before $24 \mathrm{~h}$ post-inoculation. Lipase activity (vs an olive oil emulsion) and chitinase were not detected $(₹ 40 \mathrm{~h})$ after inoculation. Protein degradation products were released from comminuted blowfly wing cuticle (Table 1) but chitin degradation products were not detected. Extraction of comminuted cuticle released $\operatorname{Pr} 1$ and $\operatorname{Pr} 2$ but failed to release chitinase (Table 1). A crude culture filtrate containing protease and chitinase released amino sugars $(4 \mathrm{nmol} \mathrm{N}$ acetylglucosamine equivalents $\left.\mathrm{ml}^{-1} \mathrm{~h}^{-1}\right)$ and amino acids $\left(32 \mathrm{nmol} \mathrm{ml} \mathrm{m}^{-1} \mathrm{~h}^{-1}\right)$ from comminuted blowfly wing cuticle $\left(0.3 \%\right.$ cuticle, $\mathrm{pH} 6.0$ at $\left.30^{\circ} \mathrm{C}\right)$ indicating that wing proteins and chitin were 


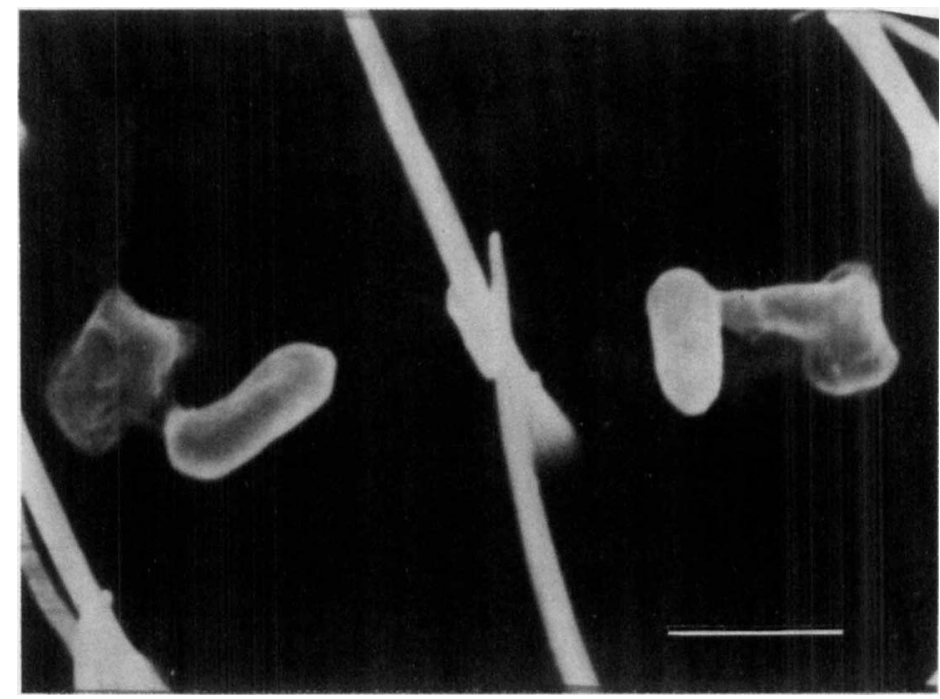

Fig. 1. Scanning electron micrograph of $M$. anisopliae $\mathrm{ME} 1$ incubated at $27^{\circ} \mathrm{C}$ for $20 \mathrm{~h}$ on an excised blowfly wing. Note conidia, short germ tubes, appressoria and penetration filaments. Bar $5 \mu \mathrm{m}$.

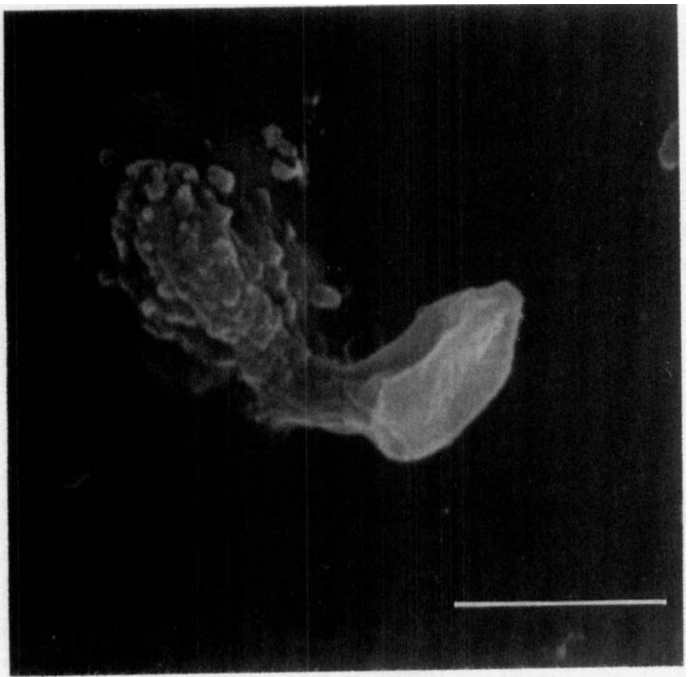

Fig. 2. Scanning electron micrograph of $M$. anisopliae MEl incubated at $27^{\circ} \mathrm{C}$ for $20 \mathrm{~h}$ on excised locust cuticle. The infected cuticle was prepared for microscopy by freeze drying to preserve the appressorial mucoid sheath. Bar $5 \mu \mathrm{m}$.

available for hydrolysis by fungal enzymes, if present. When tested vs comminuted fly wing, pure $\operatorname{Pr} 1$ released $120 \mathrm{nmol}$ alanine equivalents $\mathrm{ml}^{-1} \mathrm{~h}^{-1}\left(\operatorname{Prl}, 1 \mu \mathrm{g} \mathrm{ml}^{-1}\right.$; substrate, $10 \mathrm{mg} \mathrm{ml}^{-1}$; $\mathrm{pH} 8.0$ at $30^{\circ} \mathrm{C}$ ).

Similar experiments were done with Manduca sexta cuticle (Table 1). Extracts from cuticles contained $\operatorname{Pr} 1$ and $\operatorname{Pr} 2$ but not chitinase. Likewise comminuted infected cuticle released amino acids but not amino sugars during incubation.

\section{Histochemical localization of cuticle-degrading enzymes}

The results obtained for each histochemical test are summarized in Table 2.

Protease. Of the four substrates tested [Ben-Phe-2NA, Suc-(Ala) ${ }_{2}$-Pro-Phe-MNA, Ben-Arg2NA and CBZ-(Gly) $)_{2}$-Arg-MNA] only the peptide substrates were visibly hydrolysed (Figs 5 and 6). The specificities of $\operatorname{Pr} 1$ and $\operatorname{Pr} 2$ vs the blocked peptide-MNA substrates were 


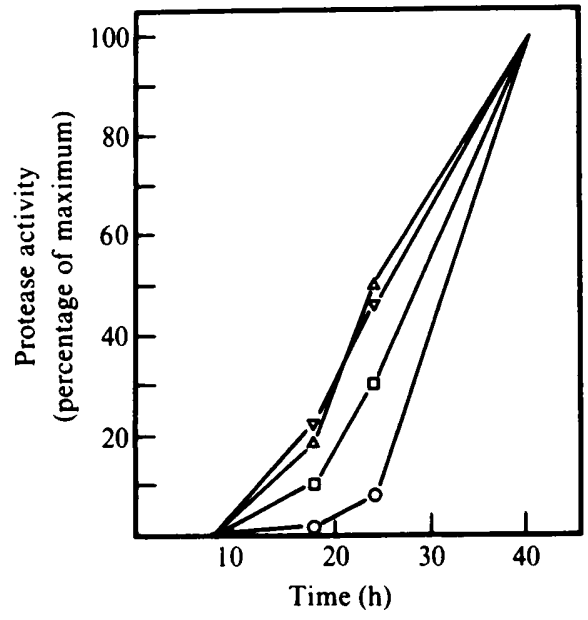

Fig. 3

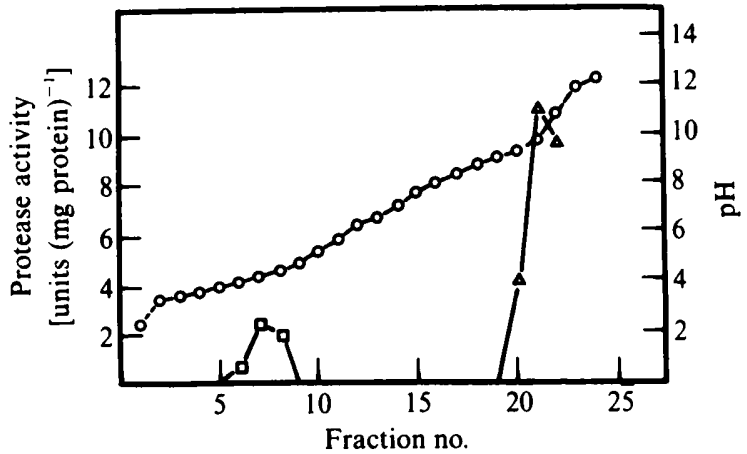

Fig. 4

Fig. 3. Cuticle degrading enzymes produced during penetration of blowfly wings. Enzymes were released by washing 10 blowfly wings ( $8 \mathrm{~h}$ post-inoculation with $M$. anisopliae) together in $5 \mathrm{ml} 0.2 \mathrm{M}$ potassium phosphate buffer, $\mathrm{pH} 7 \cdot 0$, for $1 \mathrm{~h}$. This procedure was repeated with different wings 18,24 and $40 \mathrm{~h}$ post-inoculation. Enzymes and their maximum activity were as follows: protease (vs hide protein azure) $(\nabla) 1.2 \mu \mathrm{g}$ trypsin equivalents $\mathrm{ml}^{-1} \mathrm{~h}^{-1}$; aminopeptidase $(\square) 0.11 \mu \mathrm{mol} \mathrm{ml}^{-1} \mathrm{~h}^{-1}$; esterase $(\triangle) 0 \cdot 13 \mu \mathrm{mol} \mathrm{ml}^{-1} \mathrm{~h}^{-1} ; N$-acetylglucosaminidase $(O) 26 \cdot 3 \mathrm{nmol} \mathrm{ml}^{-1} \mathrm{~h}^{-1}$. The experiment was repeated three times with similar results.

Fig. 4. Isoelectric focusing ( $\mathrm{pH} 3 \cdot 5-10 \cdot 0$ ) of chymoelastase [vs Suc-(Ala) ${ }_{2}$-Pro-Phe-NA] $\triangle$ ) and trypsin (vs Ben-Phe-Val-Arg-NA) ( $\square$ ) activities extracted from infected blowfly wings ( $30 \mathrm{~h}$ post-inoculation). $\mathrm{O}, \mathrm{pH}$.

Table 1. Extraction of enzymes from fungal-colonized cuticles and their cuticle-degrading activities

Extractable protease

(nmol NA ml-1 $\mathrm{h}^{-1}$ )

Protein degradation products (nmol ml-1)

Chitin degradation products
Prl vs Suc-(Ala) $)_{2}$-Pro-Phe-NA Pr2 vs Ben-Phe-Val-Arg-NA

pH 6.0

pH 8.0

pH 6.0

pH 8.0
Blowfly wings Manduca sexta cuticle

$\begin{array}{rc}10.4^{*} & 6.2 \dagger \\ 2.7^{*} & 0.82 \dagger \\ 14 \ddagger & 8 \S \\ 125 \ddagger & \text { ND } \\ 0 \ddagger & 0 \S \\ 0 \ddagger & \text { ND }\end{array}$

ND, Not determined.

$0.3 \%(\mathrm{w} / \mathrm{v})$ comminuted blowfly wings $(30 \mathrm{~h}$ post-inoculation) extracted $(1 \mathrm{~h})$ in potassium phosphate buffer $(0 \cdot 2 \mathrm{M}, \mathrm{pH} 7 \cdot 0)$.

$+0.5 \%(\mathrm{w} / \mathrm{v})$ comminuted Manduca sexta cuticle $(60 \mathrm{~h}$ post-inoculation) extracted $(1 \mathrm{~h})$ in potassium phosphate buffer $(0 \cdot 2 \mathrm{M}, \mathrm{pH} 7 \cdot 0)$.

$\ddagger 0.1 \%(\mathrm{w} / \mathrm{v})$ comminuted blowfly wings ( $30 \mathrm{~h}$ post-inoculation) incubated in $0.05 \mathrm{M}$-citrate/phosphate buffer (pH 6.0) or $0.02 \mathrm{M}-\mathrm{HEPES} / \mathrm{NaOH}(\mathrm{pH} 8.0$ ) for $24 \mathrm{~h}$, then filtrate assayed with ninhydrin and MBTH.

$\S 0.5 \%(\mathrm{w} / \mathrm{v})$ comminuted Manduca sexta cuticle ( $60 \mathrm{~h}$ post-inoculation) incubated in $0.05 \mathrm{M}$-citrate/phosphate buffer (pH 6.0) for $24 \mathrm{~h}$ then filtrate assayed with ninhydrin and MBTH.

determined in vitro to confirm the potential of such substrates in distinguishing between the two enzymes (Table 3). Evidently Prl and Pr2 can be distinguished on the basis of their substrate preferences.

Further confirmation was achieved in situ using specific inhibitors (Table 4). The Prl inhibitor TEI reduced activity vs Suc-(Ala) ${ }_{2}$-Pro-Phe-MNA by $71 \%$; TEI did not, however, affect activity vs CBZ-(Gly) ${ }_{2}$-Arg-MNA. Conversely, the $\mathrm{Pr} 2$ inhibitor Tos- $\mathrm{Lys}-\mathrm{CH}_{2} \mathrm{Cl}$ had a significant effect only on activity against CBZ-(Gly) ${ }_{2}$-Arg-MNA. 


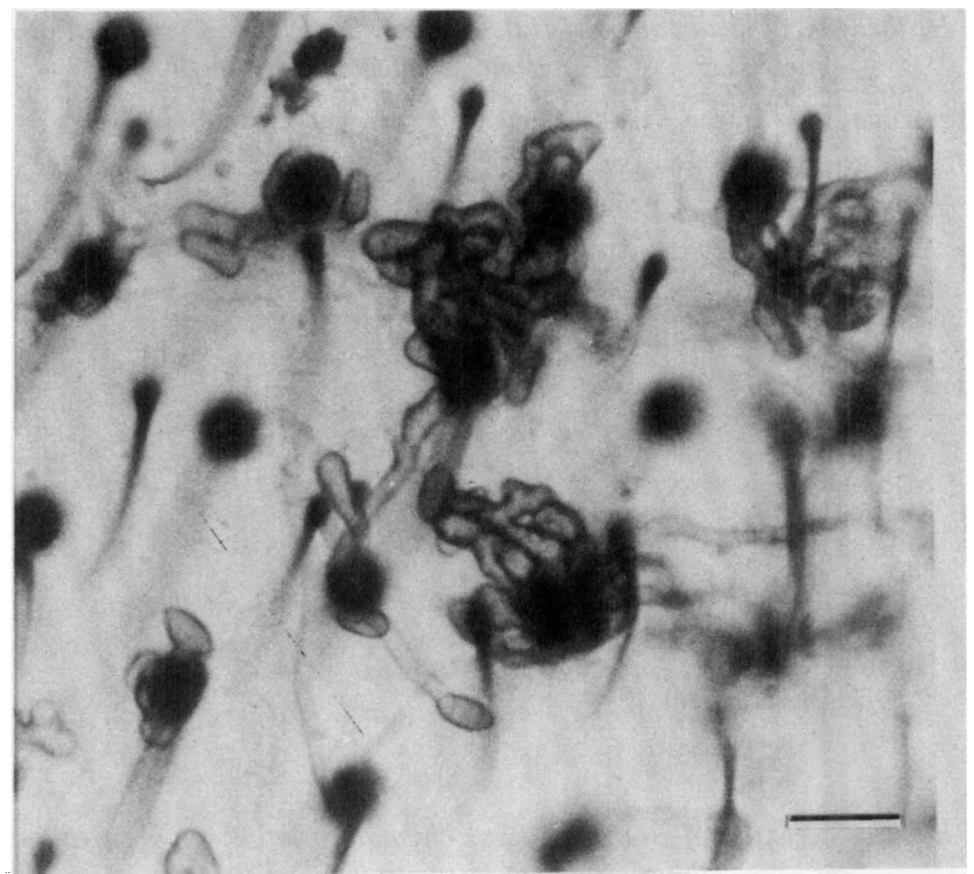

Fig. 5. Bright-field light micrograph of $M$. anisopliae ME1 $24 \mathrm{~h}$ after inoculation on to a blowfly wing, incubated in a medium (15 min) containing Suc-(Ala) $)_{2}$-Pro-Phe-MNA and FBB to demonstrate $\mathrm{Prl}$ activity on appressorial plates. Bar $10 \mu \mathrm{m}$.

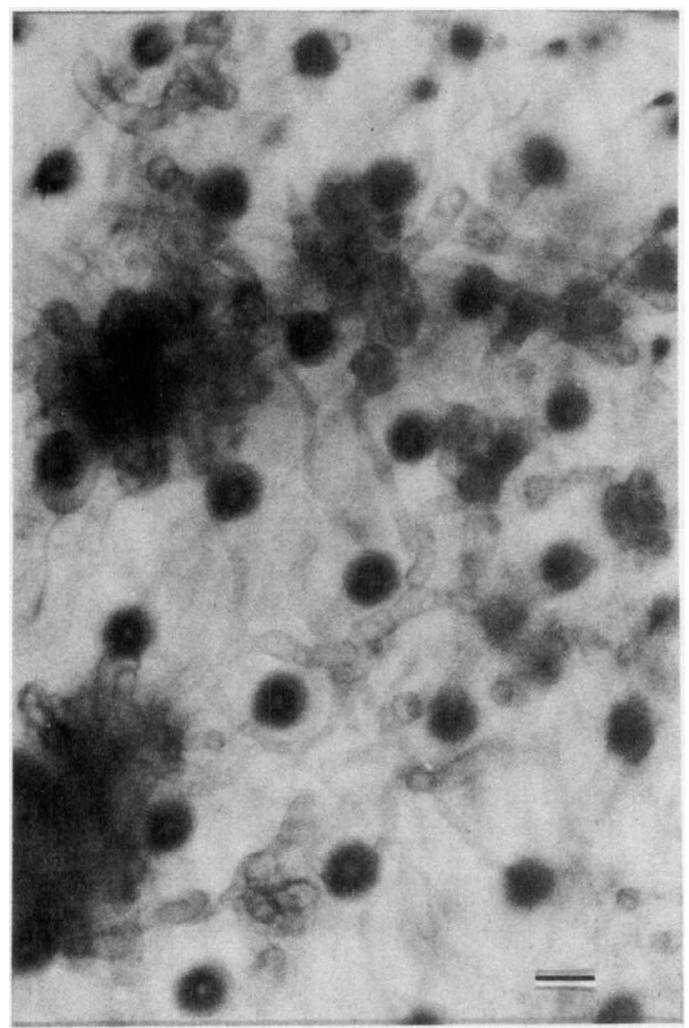

Fig. 6. Infected blowfly cuticle, $30 \mathrm{~h}$ after inoculation, incubated ( $15 \mathrm{~min}$ ) in a medium containing CBZ-(Gly) $)_{2}$-Arg-MNA and FBB to demonstrate $\operatorname{Pr} 2$ activity on appressorial plates. Bar $10 \mu \mathrm{m}$. 
Table 2. Histochemical localization of cuticle-degrading enzymes produced in situ during the early stages of $M$. anisopliae infection on blowfly wings

Positive reactions were graded weak $(+)$, moderate $(++)$ or strong $(+++) ;-$, no reaction.

\begin{tabular}{|c|c|c|c|c|c|c|c|}
\hline Activity & Substrate & $\begin{array}{l}\text { Pre-germinating } \\
\text { conidia }\end{array}$ & $\begin{array}{l}\text { Germinating } \\
\text { conidia }\end{array}$ & $\begin{array}{l}\text { Germ- } \\
\text { tubes }\end{array}$ & $\begin{array}{l}\text { Developing } \\
\text { appressoria a }\end{array}$ & $\begin{array}{c}\text { Mature } \\
\text { ippressoria }\end{array}$ & $\begin{array}{l}\text { Appressorial } \\
\text { mucilage }\end{array}$ \\
\hline \multirow[t]{2}{*}{ Protease* } & $\begin{array}{l}\text { Suc-(Ala) })_{2} \text {-Pro- } \\
\text { Phe-MNA }\end{array}$ & + & + & + & ++ & +++ & - \\
\hline & $\begin{array}{c}\text { CBZ-(Gly) })_{2-}^{-} \\
\text {Arg-MNA }\end{array}$ & + & ++ & - & ++ & $++t$ & - \\
\hline Aminopeptidase & Alanine-MNA & - & + & - & - & $++t$ & +++ \\
\hline 'Lipase' & $\begin{array}{l}\text { Tween } 40 \\
\text { Tween } 60 \\
\text { Tween } 80 \\
\text { Naphthol-AS- } \\
\text { nonanoate }\end{array}$ & $\begin{array}{l}- \\
- \\
\overline{+}\end{array}$ & $\begin{array}{l}- \\
- \\
+ \\
+\end{array}$ & $\begin{array}{l}- \\
- \\
-\end{array}$ & $\begin{array}{l}+ \\
+ \\
+ \\
+\end{array}$ & $\begin{array}{l}++ \\
++ \\
+++ \\
-\end{array}$ & $\begin{array}{l}- \\
- \\
- \\
-\end{array}$ \\
\hline Esterase & $\begin{array}{l}\text { Naphthyl- } \\
\text { propionate }\end{array}$ & ++ & ++ & $+t$ & ++ & +++ & - \\
\hline
\end{tabular}

Table 3. Relative activities of $\operatorname{Pr} 1$ and $\operatorname{Pr} 2$ vs chymotrypsin $\left(P_{1}=\right.$ phenylalanine $)$ and trypsin $\left(P_{1}=\right.$ arginine $)$ histochemical substrates

Enzyme activities are expressed as a percentage of the activity of $0.2 \mu \mathrm{g}$ enzyme towards preferred MNA substrates. The absolute values corresponding to $100 \%$ are $34.5 \Delta \mathrm{OD}_{525}(5 \mathrm{~min})^{-1}(\operatorname{Pr} 1)$ and $42 \cdot 7$ $\Delta \mathrm{OD}_{525}(5 \mathrm{~min})^{-1}(\operatorname{Pr} 2)$. Reaction conditions were $0.12 \mathrm{~mm}$-substrate, $14.4 \mathrm{~mm}$-Tris/ $\mathrm{HCl}$ buffer, $\mathrm{pH} 8.0$, at $25^{\circ} \mathrm{C}$.

- 0.12 mM-substrate, $14.4 \mathrm{mM}$-Tris/ $\mathrm{HCl}$ buffer, pH 8.0 , at $25^{\circ} \mathrm{C}$.

† Localized on septae.

Table 4. Effect of specific inhibitors on protease activity on appressorial plates (quantified as increase in integrated absorbance min $^{-1}$ )

Infected wings were pre-incubated for 10-20 min with inhibitor in $1 \mathrm{~mm}$-potassium phosphate buffer, pH 7.5; pre-incubation in buffer alone did not reduce activity.

Substrate

Suc-(Ala), $)_{2}$ Pro-Phe-MNA

CBZ-(Gly) $)_{2}$-Arg-MNA

Ala-MNA

Leu-MNA
Inhibitor

PMSF (20 min, $2 \mathrm{~mm}$ )

TEI $\left(20 \mathrm{~min}, 100 \mu \mathrm{g} \mathrm{ml}^{-1}\right)^{*}$

Tos-Lys- $\mathrm{CH}_{2} \mathrm{Cl}\left(10 \mathrm{~min}, 50 \mu \mathrm{g} \mathrm{ml}^{-1}\right)$

PMSF (20 min, $2 \mathrm{~mm}$ )

TEI $\left(20 \mathrm{~min}, 100 \mu \mathrm{g} \mathrm{ml}^{-1}\right)$

Tos-Lys- $\mathrm{CH}_{2} \mathrm{Cl}\left(10 \mathrm{~min}, 50 \mu \mathrm{g} \mathrm{ml}^{-1}\right)$

PMSF (20 min, $2 \mathrm{mM}$ )

1,10-phenanthroline (10 $\mathrm{min}, 1 \mathrm{mM}$ )

EDTA (20 $\mathrm{min}, 5 \mathrm{~mm}$ )
Enzyme activity

$\begin{array}{cc}\text { Pr1 } & \text { Pr2 } \\ 1.8 & 100 \\ 100 & 0.35\end{array}$




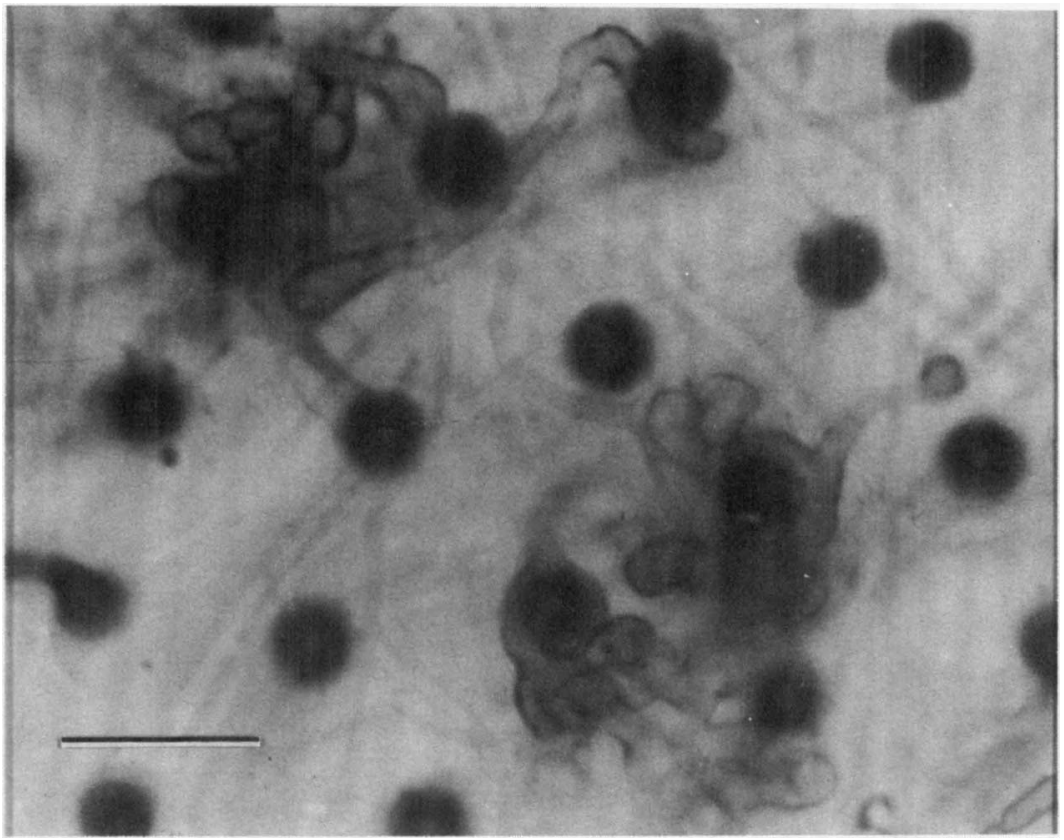

Fig. 7. Infected blowfly cuticle, $24 \mathrm{~h}$ after inoculation, incubated $(5 \mathrm{~min})$ in a medium containing AlaMNA and FBB to demonstrate aminopeptidase activity on appressorial plates. Bar $10 \mu \mathrm{m}$.

PMSF inhibited activity against either substrate by about $80 \%$ confirming that the activities detected in situ both result from serine enzymes. Activities were unaffected by incubation (20 $\mathrm{min})$ with EDTA $(10 \mathrm{mM}), 1,10$-phenanthroline $(1 \mathrm{mM})$ or ethylmaleimide $(2 \mathrm{mM})$.

Aminopeptidase. No differences were detected between the sites of enzyme activities localized with alanyl-MNA (Fig. 7) and leucyl-MNA though staining with the alanyl derivative was about 6.5 times more intense (Table 4). Aminopeptidase activity differed from protease in that it was not present on immature appressoria, and the activity extended into the mucilage surrounding mature appressoria and appressorial plates. The activity was inhibited by 1,10-phenanthroline and EDTA, but not by PMSF. Aminopeptidase was also studied in slide cultures. As on insect cuticles, high activity was associated with appressoria (Fig. 8).

Esterase. No difference in enzyme localization was detected with $\alpha$-naphthyl acetate $\left(C_{2}\right)$ and $\alpha$-naphthyl propionate $\left(\mathrm{C}_{3}\right)$, but staining with the propionate derivative was in all instances far more intense.

Hydrolysis of $\alpha$-naphthyl propionate was apparent after 5 min incubation with pregerminating conidia and with appressoria. In common with protease and aminopeptidase, germ tubes showed only trace levels of esterase activity though some staining of septae occurred. Preincubation for $30 \mathrm{~min}$ with PMSF almost completely inhibited esterase activity.

Lipase. The extent of activity and the localization of reaction products varied with the Tween substrate used (Table 2); cytochemical localization in appressoria was only obtained using Tween 80 (unsaturated ester of oleic acid). Pre-incubation for $30 \mathrm{~min}$ with PMSF substantially reduced amounts of precipitate.

Enzyme activity detected with naphthol-AS-nonanoate $\left(\mathrm{C}_{9}\right)$ and FBB was limited almost entirely to conidia even when incubation periods were extended to $4 \mathrm{~h}$.

\section{Fluorescence staining of fungal structures}

Appressoria produced terminally or laterally to hyphae on cuticle or slide cultures fluoresced with Calcofluor M2R New or FITC-WGA. Other fungal structures fluoresced only weakly. No 


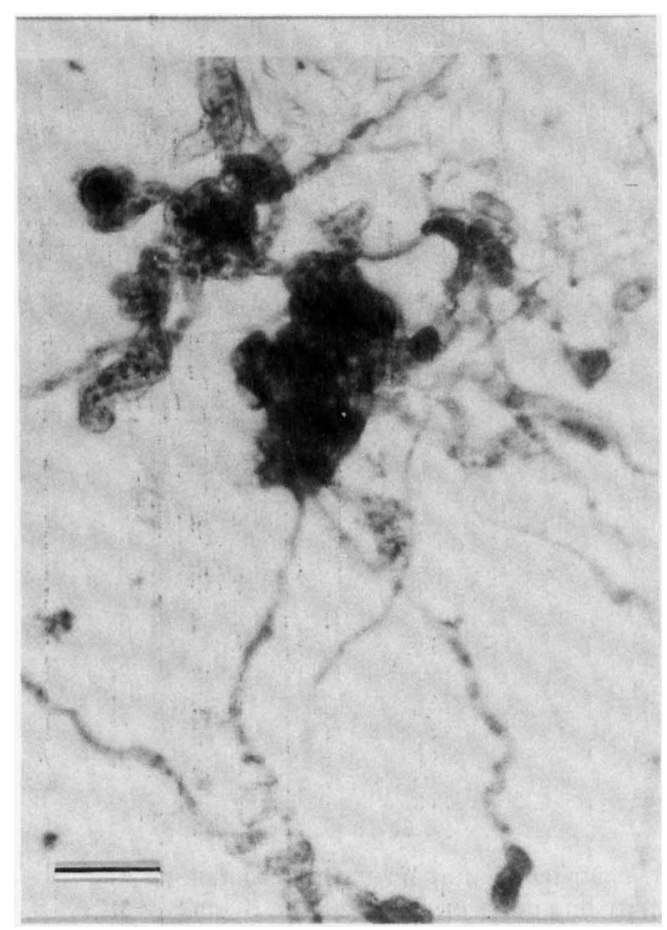

Fig. 8. Hyphal growth against a glass surface, $72 \mathrm{~h}$ after inoculation, incubated $(5 \mathrm{~min})$ in a medium containing Ala-MNA and FBB to demonstrate aminopeptidase activity. Bar $10 \mu \mathrm{m}$.

labelling with FITG-WGA was observed when the colonies were pre-incubated with nonfluorescent WGA or when treated with FITC-WGA pre-incubated $\left(30 \mathrm{~min}\right.$ at $\left.35^{\circ} \mathrm{C}\right)$ with chitotriose (2 mM), a specific inhibitor of the lectin (Mirelman et al., 1975).

\section{DISCUSSION}

Histochemical studies detected lipase/esterase and protease activity on conidia, on host cuticle and during all stages of germination but high levels were associated only with formation of appressoria. High aminopeptidase activity was detected only on mature appressoria at penetration. Production of aminopeptidase on slide cultures demonstrates its constitutive nature and it follows that any influence the host surface has on aminopeptidase production is likely to be indirect, i.e. through influencing appressorial formation rather than by providing inducers of enzyme synthesis.

Appressorial cell walls may, like apical walls before deposition of secondary wall material (Chang \& Trevithick, 1974), allow enzymes and mucus polymers to diffuse unimpeded and so become extracellular. Staining of $M$. anisopliae for wall $\beta$-glucans with Calcofluor MR2 New or for chitin with FITC-WGA revealed that regions producing mucus and cuticle-degrading enzymes, i.e. appressoria and hyphal tips, possessed much higher amounts of stainable glucans than associated germ-tubes. Similarly, apical tips of Botrytis cinerea stain with Calcofluor due to local cell wall lysis in areas of cell expansion (Gull \& Trinci, 1974).

The potential role in pathogenesis of the enzymes identified in vivo could be predicted from their properties and the known structure of the cuticle. Lipids of the epicuticle predominate in the environment of germinating conidia. However, doubts as to the involvement of lipases must be raised by the inability to extract 'true lipase' from infected cuticle. Obviously non-detection may have reflected numerous factors such as binding of lipase to fungal cell walls and host cuticle components. The distinction between lipases and esterases in a histochemical system is very difficult (Luppa \& Andra, 1982). Because of lack of substrate specificity the Tweenhydrolysing enzyme detected in vivo cannot be categorically identified with the lipase produced 
in vitro (Pearse, 1972). Most microbial lipases are serine enzymes (Brockerhoff \& Jensen, 1974) and in that respect would not be distinguished from the non-specific esterases produced by $\boldsymbol{M}$. anisopliae. The different sites of activities against Tween 80 (localized on appressoria) and naphthol-AS-nonanoate (localized on conidia) suggest that the enzyme degrading Tween is distinguishable from at least one medium-chain-length non-specific esterase.

The major cuticular component is protein which masks microfibrillar chitin (Neville, 1975). Prl solubilizes pro-cuticular proteins more effectively than any other endoprotease obtained from $M$. anisopliae or commercial sources, and is likely to be the principal enzyme involved in cuticle degradation (St Leger et al., 1987). The detection of Prl by biochemical, immunological and histochemical means during cuticle penetration confirms this enzyme as a likely major determinant of pathogenicity. The action of $\mathrm{Prl}$ releases peptides, mean residue length five (St Leger et al., 1986 b), which may be further degraded and rendered amenable for uptake and metabolism by the aminopeptidase(s) produced during penetration. In this context, the preference for alanyl compared with leucyl histochemical substrates is noteworthy as alanine is the major amino acid component of insect cuticle and supports better growth of $M$. anisopliae than other amino acids (St Leger et al., 1986a,b).

Production of enzymes in vitro on locust cuticle as sole carbon source occurs sequentially over several days with chitinases among the last enzymes produced (St Leger et al., 1986a). Likewise, production of proteolytic enzymes preceded that of $\mathrm{N}$-acetylglucosaminidase (exochitinase) during infection of fly wings. There was no evidence for the production of an active endochitinase during the $40 \mathrm{~h}$ period following inoculation. The late appearance of inducible chitinase in vitro may be due to the delayed exposure of chitin and release of inducers which requires the previous action of proteases (St Leger et al., 1986a,c). However, as with lipase the apparent absence of chitinase from infected blowfly and Manduca sexta cuticles could be due to inadequate extraction or inhibitors in the cuticle [chitinase in vitro binds tightly to locust chitin in a non-ionic manner (St Leger et al., 1986d)]. Attempts to detect chitinase activity in vitro using ethylene glycol chitin as a potential histochemical substrate were thwarted by $\mathrm{N}$ acetylglucosaminidase activity against soluble chitins (unpublished data). Nevertheless, failure to detect the products of chitin hydrolysis in comminuted infected cuticle indicates that the activity of chitinase, if present, is negligible compared to that of protease. This apparent absence during infection suggests that chitinase is not involved in the initial cuticular penetration by $\boldsymbol{M}$. anisopliae. Perhaps, therefore, chitinase functions largely to provide nutrients during the saprophytic phase of fungal growth in cuticles of moribund insect hosts.

The sequence of enzyme production (protease and esterase, aminopeptidase, $N$-acetylglucosaminidase) may reflect the order of gene expression during differentiation of appressoria. There have been no studies on the biochemical events relating to germination and differentiation in entomopathogens. Work with the phytopathogen Uromyces phaseoli has suggested that DNA and RNA replication are involved in construction of the appressorium (Ramakrishnan \& Staples, 1970; Staples \& Hoch, 1984), and the synthesis of many new proteins which may appear sequentially (Staples \& Hoch, 1984). The initiation of appressoria may be the trigger for a sequence of pathogenicity factors which, in $M$. anisopliae, includes production of cuticledegrading enzymes.

Finance for this study was provided by the AFRC. The electron microscope was SERC-funded equipment. We are grateful to Dr Marion Lamb for allowing us to use the Vickers M86 microdensitometer at Birbeck College, University of London.

\section{REFERENCES}

BeLl, R. A. \& JoAChim, F. G. (1976) Techniques for rearing laboratory colonies of tobacco hornworms and pink bollworms. Annals of the Entomological Society of America 69, 365-375.

BROCKERHOFF, H. \& JENSEN. R. G. (1974). Lipolytic Enzymes. New York \& London: Academic Press.
Chang, P. L. Y. \& Trevithick, V. R. (1974). How important is secretion of enzymes through apical cell walls of fungi? Archives of Microbiology 101, 281293.

Charnley, A. K. (1984). Physiological aspects of destructive pathogenesis in insects by fungi: a 
speculative review. In Invertebrate-Microbial Interactions, pp. 229-270. British Mycological Society Symposium no. 6. Edited by J. M. Anderson, A. D. M. Rayner \& D. W. H. Walton. Cambridge: Cambridge University Press.

FARGUES, J. (1984). Adhesion of the fungal spore to the insect cuticle in relation to pathogenicity. In Infection Processes of Fungi, pp. 90-111. Edited by D. W. Roberts \& J. R. Aist. New York: The Rockefeller Foundation.

GABRIEL, B. P. (1968). Histochemical study of the insect cuticle infected by the fungus Entomophthora coronata. Journal of Invertebrate Pathology 11, 82-89.

GOMORI, G. (1945). The microtechnical demonstration of sites of lipase activity. Proceedings of the Society for Experimental Biolog! and Medicine 58, 362-364.

Gull, K. \& TrinCI, A. P. J. (1974). Detection of areas of wall differentiation in fungi using fluorescent staining. Archives of Microbiology 96, 53-57.

HaCKMAN, R. H. (1980). Biochemical methods (proteins). In Cuticle Techniques in Arthropods, pp. 145184. Edited by T. A. Miller. New York: SpringerVerlag.

LUPPA, H. \& ANDRA, J. (1982). The histochemistry of carboxylester hydrolases: problems and possibilities. Histochemical Journal 15, 111-137.

Mirelman, D., Galun, E., Sharon, N. \& Lotan, R. (1975). Inhibition of fungal growth by wheat germ agglutinin. Nature, London 256, 414-416.

MOORE, S. \& SteIN, W. H. (1948). Photometric ninhydrin method for use in the chromatography of amino acids. Journal of Biological Chemistry 76, 367388.

Neville, A. C. (1975). Biology of the Arthropod Cuticle. Berlin: Springer-Verlag.

PeArse, A. G. E. (1972). Histochemistry, Theoretical and Applied, vol. 2, 3rd edn. Edinburgh \& London: Churchill Livingston.

Ramakrishnan, L. \& Staples, R. C. (1970). Changes in ribonucleic acids during uredospore differentiation. Phytopathology 60, 1087-1091.

Ratault, C. \& Vey, A. (1977). Production d'esterases et de $N$-acetyl- $\beta$-D-glucosaminidase dans le tegument du Coleoptere Oryctes rhinoceros par le champignon entomopathogene Metarhizium anisopliae. Entomophaga 22, 289-294.

Smith, L. R. \& Gilkerson, E. (1979). Quantitation of glycosaminoglycan hexosamine using 3-methyl-2benzothiazolone hydrazone hydrochloride. Analytical Biochemistry 98, 478-480.

StaPles, R. C. \& Hoch, H. C. (1984). A sensing mechanism in rust uredospore germlings responsive to host morphology starts the cell cycle. In Infection Processes of Fungi pp. 126-136. Edited by D. W. Roberts \& J. R. Aist. USA: The Rockefeller Foundation.

Starkey, P. M. \& BarretT, A. J. (1976). Human lysosomal elastase, catalytic and immunological properties. Biochemical Journal 155, 265-271.

Stevenson, G. T. (1974). Immunisation with antigen coupled to an immunosorbent Nature, London 247 , 477-478.

St Leger, R. J., Charnley, A. K. \& Cooper, R. M. (1986a). Cuticle degrading enzymes of entomopathogenic fungi. Synthesis in culture on cuticle. Journal of Invertebrate Pathology 48, 85-95.

St Leger, R. J., CoOper, R. M. \& Charnley, A. K. (1986b). Cuticle degrading enzymes of entomopathogenic fungi: cuticle degradation in vitro by enzymes from entomopathogens. Journal of Invertebrate Pathology 47, 167-177.

St leger, R. J., CoOper, R. M. \& Charnley, A. K. $(1986 c)$. Cuticle-degrading enzymes of entomopathogenic fungi: regulation of production of chitinolytic enzymes. Journal of General Microbiology 132 , $1509-1517$.

St Leger, R. J., Charnley, A. K. \& CoOper, R. M. $(1986 d)$. Cuticle-degrading enzymes of entomopathogenic fungi: mechanisms of interaction between pathogen enzymes and insect cuticle. Journal of Invertebrate Pathology 47, 295-302.

St Leger, R. J., Charnley, A. K. \& CoOper, R. M. (1987). Characterization of cuticle-degrading proteases produced by the entomopathogen Metarhizium anisopliae. Archices of Biochemistry and Biophysics 253, 221-232. 